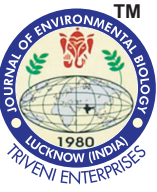

\title{
Influence of Hexanal formulation on storage life and post-harvest quality of mango fruits
}

Authors Info

P. Preethi ${ }^{1 *}$,

K. Soorianathasundaram ${ }^{1}$

A. Sadasakthi', K.S. Subramanian',

G. Paliyath ${ }^{2}$ and J. Subramanian

${ }^{1}$ Horticultural College and Research Institute, Tamil Nadu Agricultural University, Coimbatore - 641 003, India

${ }^{2}$ Department of Plant Agriculture, University of Guelph,

Guelph - 519, Canada

*Corresponding Author Email : pppreethifruitscience@gmail.com

\section{Key words}

Hexanal

Mango

Post-harvest quality

Storage life

\section{Publication Info}

Paper received : 01.11 .2017

Revised received: 11.12.2017

Re-revised received: 19.12 .2017

Accepted: 03.01.2018

\section{Abstract}

Aim : The objective of the present study was to investigate the influence of hexanal formulation on delaying ripening as well as its impact on quality attributes of mango cultivars Banganapalli and Alphosno.

Methodology : Treatments included $2 \%$ hexanal formulation pre-harvest spray at $15^{\text {th }}$ and $30^{\text {th }}$ day before harvest, post-harvest dip for two minutes, combination of spray and dip and no spray and dip stored at ambient and cold storage condition.

Results : The physiological parameters revealed loss in weight, respiration rate, ethylene evolution rate and fruit firmness of fruits subjected to combination of pre-harvest spray and post-harvest dip with hexanal formulation and kept in cold storage were superior as compared to control under ambient storage condition. Treatments with hexanal formulation significantly influenced total sugars, total carotenoids and total flavonoids in the fruits. Ascorbic acid content and total antioxidant activity was enhanced in pre- and postharvest hexanal formulation treatments as compared to control by $11 \%$ and $28 \%$. The effect of hexanal formulation as pre-harvest spray and post-harvest dip extended the shelf life of mango fruits from 5 days to 10 days in ambient storage and from 12 days to 20 days in cold storage.

Interpretation : Pre and post-harvest hexanal formulation treatments along with cold storage offers significant promise to increase the post-harvest fruit quality and reduce post-harvest losses in mango.

Post-harvest behaviour of hexanal treated mango fruits

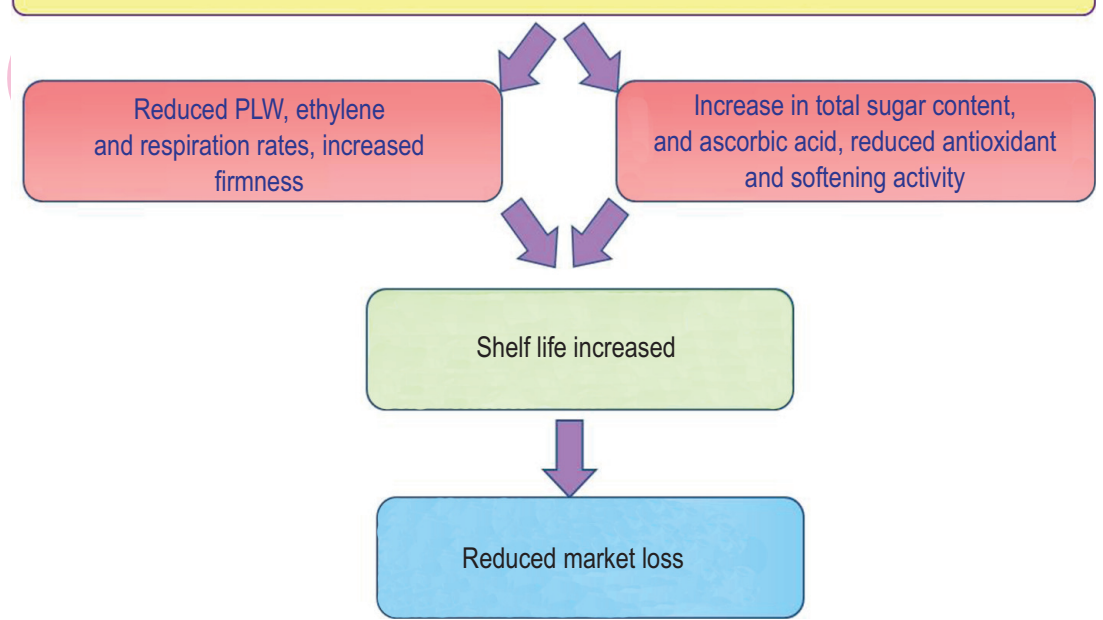




\section{Introduction}

Mango (Mangifera indica Linn.), a widely acclaimed fruit of India, is known for its delicious taste, excellent flavor and rich nutritional content, especially vitamins A and C. Mango currently ranks fifth in total production among major fruit crops worldwide (National Horticultural Board, 2016), with India ranking first in mango production. Mango is a climacteric fruit, hence easily perishable and highly vulnerable to post-harvest diseases and damage during transit etc. Several factors, such as cultivar, stage of maturity, harvesting methods, size grading, handling, packaging and mode of transport affect the storability of mango fruits. The internal factors like respiratory processes, ethylene evolution, enzymatic starch hydrolysis and other carbohydrate hydrolases leads to cell wall softening and subsequent post-harvest deterioration in fruits (Akamine and Goo, 1973). Thus, technologies to enhance mango postharvest life and market distribution is receiving huge attention of late, as there is a huge demand for domestic consumption as well as export trade.

Many new technologies have been developed and standardized for extending the shelf life of mango fruits including application of chemicals (Babalar et al., 2007; Sharma et al., 2009) growth regulators (Reddy et al., 2016), hot water treatment, wax treatment and refrigerated storage (Bretch and Yahia, 2009). In addition, a new formulation based on hexanal has been found to enhance the shelf life of many fruit crops viz., apple, pears, peach, grapes, sweet cherries, guava, mango and strawberry (Corbo et al., 2000; Spotts et al., 2007; Paliyath and Murr, 2008). Hexanal is a naturally occurring six carbon aldehyde compound produced in the lipoxygenase pathway and released from plants during tissue damage. It is an important precursor for the formation of six carbon alcohols and esters, with an important role in extending fruit freshness by inhibiting the enzyme phospholipase-D (Brown et al., 1990; Jandus et al., 1997). Several studies have been carried out in enhancing the shelf life and post-harvest quality of temperate fruits.

In the view of above, an attempt was made to investigate the action of hexanal formulations on post-harvest behaviour in two mango cultivars.

\section{Materials and Methods}

Experimental fields and biological materials : The experiment was conducted in mango orchards in Krishnagiri district of Tamil Nadu subsequently for three seasons. Healthy and uniform sized 10-15 year old mango trees of promising cultivars Banganapalli and Alphonso were selected and sprayed with $2 \%$ hexanal formulation as applied twice ( $15^{\text {th }}$ and $30^{\text {th }}$ day before harvest) and trees with no spray were considered as control. Approximately, 15 I of spray fluid was required to completely drench the crown region. The harvested fruits were transported to Tamil Nadu Agricultural University, Coimbatore under refrigerated wagon with $13 \pm 2^{\circ} \mathrm{C}$ and sorted for uniform size. Pre-harvest sprayed fruits were divided into two sets for dipping treatment with $2 \%$ hexanal formulation for 2 min and no dip. Similarly, two sets of control fruits, with $2 \%$ hexanal formulation dip for $2 \mathrm{~min}$. and no dip were stored at room temperature (temperature $-25 \pm 2^{\circ} \mathrm{C}, \mathrm{RH}-55 \pm 3 \%$ ) and cold storage (temperature $-13^{\circ} \mathrm{C}, \mathrm{RH}-90 \pm 3 \%$ ) for further post-harvest quality analysis.

Observation recorded : Samples were periodically drawn from ambient and cold storage at the rate of six fruits for each treatment and the mean value arrived for each of the following parameters.

Physiological parameters : Firmness of the fruit was measured at three different stage (proximal, distal and middle portion) according to Jha et al. (2013) by measuring the force required to puncture the fruit using penetrometer (FG 5000a, Taiwan) and the mean force was expressed in Newton. The shelf life of mango recorded by observing the number of days taken from the first day of storage until it reached the stage, wherein the fruit becomes unfit to consume.

Physiological loss in weight (PLW) was calculated as [Initial weight-Final weight/Initial weight] x 100.The ethylene evolution rate and respiration rate of mango fruits were measured using the static headspace technique as described by Singh and Rao (2005). Ethylene evolution rate was calculated under both ambient and cold storage conditions using ethylene analyzer (Range: 0-100 ppm Ethylene; Resolution: $0.1 \mathrm{ppm}$; Temperature range: $0-35^{\circ} \mathrm{C}$; Pump Flow : Typically 0.8 I $\mathrm{min}^{-1}$; Make: Bioconservacion, Spain). The respiration rate of treated and untreated mango fruits of known volume was measured using auto gas analyzer (Model : PBI Dansensor, checkpoint, $\mathrm{CO}_{2} / \mathrm{O}_{2}$ gas analyser, Denmark)

Biochemical parameters : Estimation of total soluble solids (TSS) was determined using a digital refractometer (PAL 3, Atago Ltd., Japan) at $25^{\circ} \mathrm{C}$ temperature and it was expressed in degree Brix ( ${ }^{\circ}$ Brix). Total sugars present in mango fruits was estimated using Anthrone reagent (Hedge and Hofreiter, 1962). Ascorbic acid was estimated according to AOAC (1990) and expressed as $\mathrm{mg} 100 \mathrm{~g}^{-1}$ of pulp. One gram of fruit pulp was used to estimate the carotenoid content (Jensen, 1978) and expressed as $\mathrm{mg} \mathrm{g}^{-1}$ of pulp. Total flavonoid content was estimated by the method of Zhishen et al. (1999) and expressed as milligrams of catechin equivalents $100 \mathrm{~g}^{-1}$ pulp. Total antioxidant activity was estimated by the method of Prieto et al. (1999) and expressed in $\mathrm{mg}$ ascorbic acid equivalence $100 \mathrm{~g}^{-1}$ pulp.

The activity of antioxidant enzymes peroxidase (POX) (Mallik and Singh, 1980) and catalase (CAT) (Luck, 1974), and fruit softening enzymes pectin methylesterase (PME) (Hagerman and Austin, 1986) and polygalacturonase (PG) (Zainon and Brady, 1982) were also determined.

Statistical analysis : Effect of treatments on the observed parameters were analysed in a completely randomized block design at $5 \%$ significance level using AGRESS software.

\section{Results and Discussion}

Hexanal formulation enhanced the shelf life of mango fruits (Fig.1A) by maintaining the fruit firmness (Fig.1B). 
Application of higher dose of hexanal enhanced the shelf life to about 8-9 days under ambient and 18-20 days under cold storage. However, control fruits could be stored upto 5 days in ambient and 12 days under cold condition across the cultivars. The force required to pierce fruits, so called fruit firmness were determined by the water content and moisture retention capacity of tissues. During ripening, the soluble enzyme phospolipase-D (PLD) involved in breaking the hydrogen double bond between calcium molecules and dissociated calcium molecules was replaced by PLD, thereby initiating membrane degradation and firmness loss. Hexanal is an effective action inhibitor of PLD associated with cell membrane and preserves the cell membrane integrity after harvest (Paliyath and Murr, 2008). In fruit firmness, significant difference was observed among the treatments regardless of cultivars. Higher dose of hexanal maintained the mean fruit firmness upto $35 \%$ in cv. Banganapalli and $45 \%$ in cv. Alphonso irrespective of storage conditions. Similar to this experimental results, hexanal increased the post-harvest longevity of mango (Anusuya et al., 2016; Jincy et al., 2017) apple, pear and strawberry (Paliyath and Subramanian, 2008), tomato (Oke et al., 2003; Pinhero et al., 2003) and sweet cherry (Sharma et al., 2010). Between the cultivars studied, the shelf life of cv. Alphonso was found to be little more than cv. Banganapalli. According to Gunjate et al. (1982) cv. Alphonso has inherited to release high levels of hexanal and hexanol.

The physiological loss in weight of harvested fruits and vegetables is a major cause of quality and economic loss and limits the storage life. The percentage of physiological weight loss varies with physical and morphological characters viz., skin thickness, epicuticular wax and epidermis cells of a genotype, pre- and post-harvest practices and storage atmosphere (Nunes et al., 2007; Bretch and Yahia, 2009). Retention of substantial amount of moisture content is essential to maintain cell shape, internal turgor pressure of the cell and to regulate bio-enzymatic pathway (Lownds et al., 1993). Regardless of mango cultivars, storage conditions and treatments, PLW was observed to vary throughout the storage period (Fig. 1C). The drastic PLW was observed in ambient storage (20\%) than cold storage condition $(5 \%)$. The spray and dip treatment of hexanal increased the physiological weight retention percentage of mango fruits upto 93$94 \%$ invariable to cultivars and storage conditions. The physiological weight retention was significant when spray and dip treated fruits were stored under cold condition.

In mango, ethylene production was accelerated after being detached from mother plant due to release of anti-ethylene substance from mother plant that inhibited the ripening activity (Burg and Burg, 1965). The evolution rate of ethylene in mango fruits was considerably increased after harvest, regardless to cultivars and storage conditions (Fig. 1D). The spray and dip treatment of hexanal drastically reduced the ethylene evolution rate under ambient and cold storage condition. Nearly, three times reduction in ethylene evolution rate was recorded in cold stored spray and dip treated fruits $\left(9.26 \mu \mathrm{C}_{2} \mathrm{H}_{4} \mathrm{~kg}^{-1} \mathrm{hr}^{-1}\right)$ than ambient stored control fruits $\left(3.50 \mu \mathrm{C}_{2} \mathrm{H}_{4} \mathrm{~kg}^{-1} \mathrm{hr}^{-1}\right)$. Similar trend was also observed with respect to respiration rate under ambient and cold storage conditions. Three fold deductions in respiration rate was recorded in higher dose hexanal treated fruits under cold storage (19.37 mg CO $\mathrm{kg}^{-1} \mathrm{hr}^{-1}$ ) than ambient control fruits (58.64 $\left.\mathrm{mg} \mathrm{CO}_{2} \mathrm{~kg}^{-1} \mathrm{hr}^{-1}\right)$ across the cultivars. Hexanal is a green volatile phytocompound that tends to increase the green flavor in fruits and vegetables (Schade et al., 2003; Gigot et al., 2010). While fruit ripening, concentration of ethylene increases and hexanal decreases. Hexanal delays ripening and extends the green flavor emission in mango fruits. Hence, spray and spray dip hexanal formulation treated mango fruits gradually emitted hexanal and enhance the shelf life. With response to increasing ethylene evolution rate, the respiration rate also increased (Fig. 1E). Hexanal preserves the membrane integrity and fatty acids that contributed to flavor profile of fruits. Application of higher dose hexanal formulation before acceleration of membrane detoriation combined with cold storage had best effect on reducing the respiration rate in mango fruits. The lower ethylene evolution rate and respiration rate indicated the slowdown in ripening process. Exogenous application of hexanal application before and after harvest, reduces the lipoxegenase activity in mango fruit peel and would have assisted in delaying fruit ripening and lower PLW. The effect of hexanal on other vegetables and fruits were obtained for similar results (Spotts et al., 2007; Anusuya et al., 2016).

Biochemical quality parameters such as TSS, total sugars, ascorbic acid and colour development are some of characteristics that decide the desirability of mango fruits. Increase in soluble solids and hydrolysis of starch, present in the chloroplast to simple sugar units, are important compositional changes that takes place during fruit ripening (Singh et al., 2012; Hossain et al., 2014). Invariable to concentration, hexanal had a synergistic effect on TSS and total sugars of mango fruits at the end of storage period (Table 1.). Application of hexanal formulation twice or thrice, showed significant increase in total sugars compared to control fruits in both the cultivars. But, similar trend was not observed in TSS with respect to hexanal application. Breakdown of stored carbohydrates is an important catalytic activity in improving the quality of fruits. In hexanal treated fruits, prominence of starch granules could be observed in between the parenchyma cells in pulp which is indicative of delay in the ripening process as against the absence of such starch granules in control fruits. It is possible that the starch were acted upon by amylase enzyme, the activity of which corresponds to ripening stage. In studies by Lima et al. (2001), the climacteric raising in mango fruit is marked by an appreciable increase in the activity of amylase, reducing and non-reducing sugars contents and decrease in the starch content. Hexanal application may slow down the activity of amylase and improve the total sugars by gradual degradation of starch granules, thinning of parenchyma tissue and maintained the structural integrity during storage (Fig .2).

During fruit ripening process, degradation of chlorophyll and synthesis of carotenoids or xanthophylls takes place simultaneously. The quantity of carotenoids in mango fruits will 

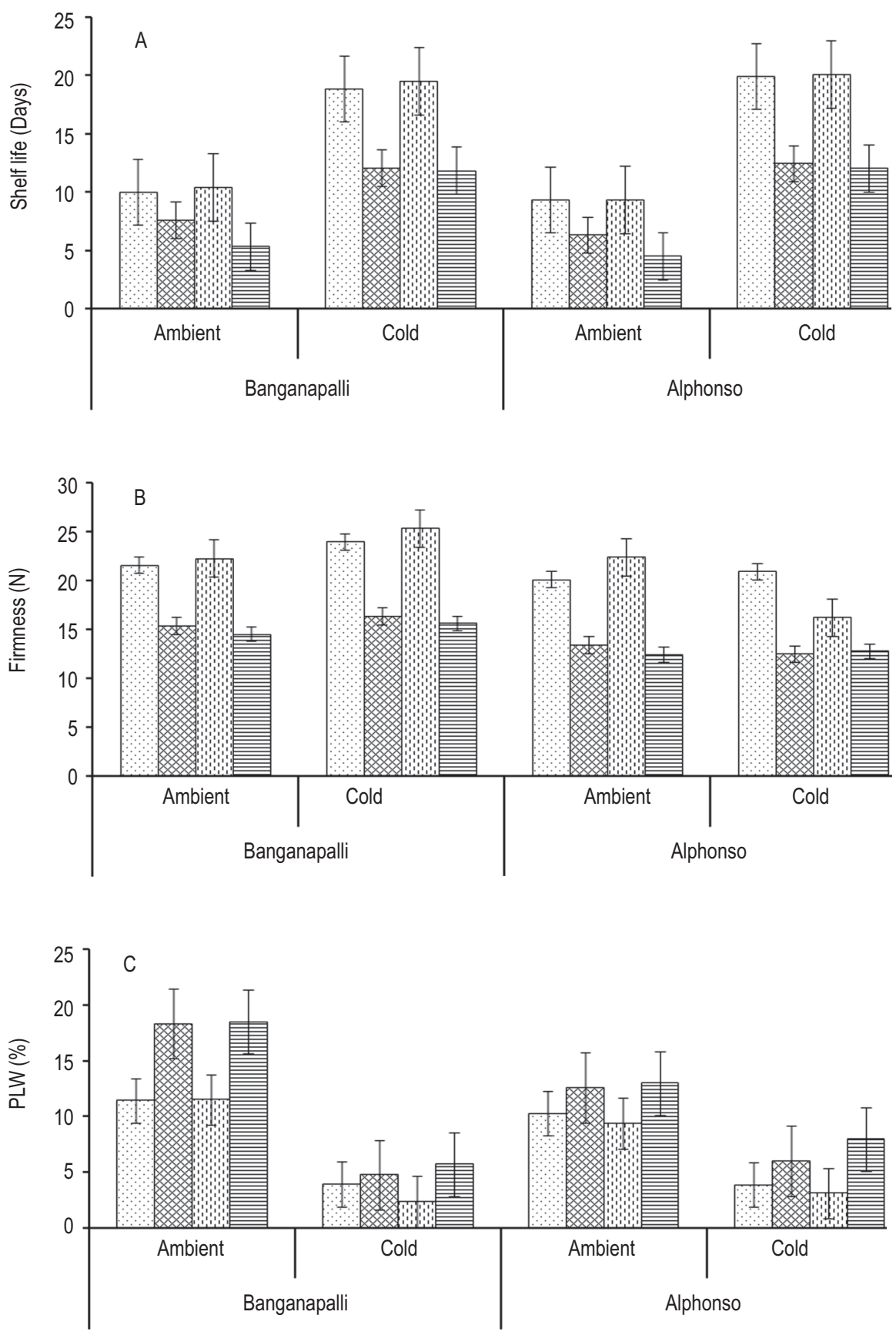

determine its colour and combat free radical produced by human body by various physiological processes (Graf et al., 2005; Huang et al., 2005). Carotenoids and flavonoids are major secondary metabolites produced during biochemical pathway. A non linear rise in total carotenoid and total falvonoid content was observed with respect to hexanal concentration (Table 1). Though, positive significance had been observed in hexanal application with respect to carotenoids and flavonoids in cv. Banganapalli, similar trend was not observed in cv. Alphonso. The ambient and cold storage effect were not consistent with respect to total carotenoid and total flavonoid. Hexanal acts on polyphenols substance like lignin in cell wall which is a strong antioxidant, conjugates with 

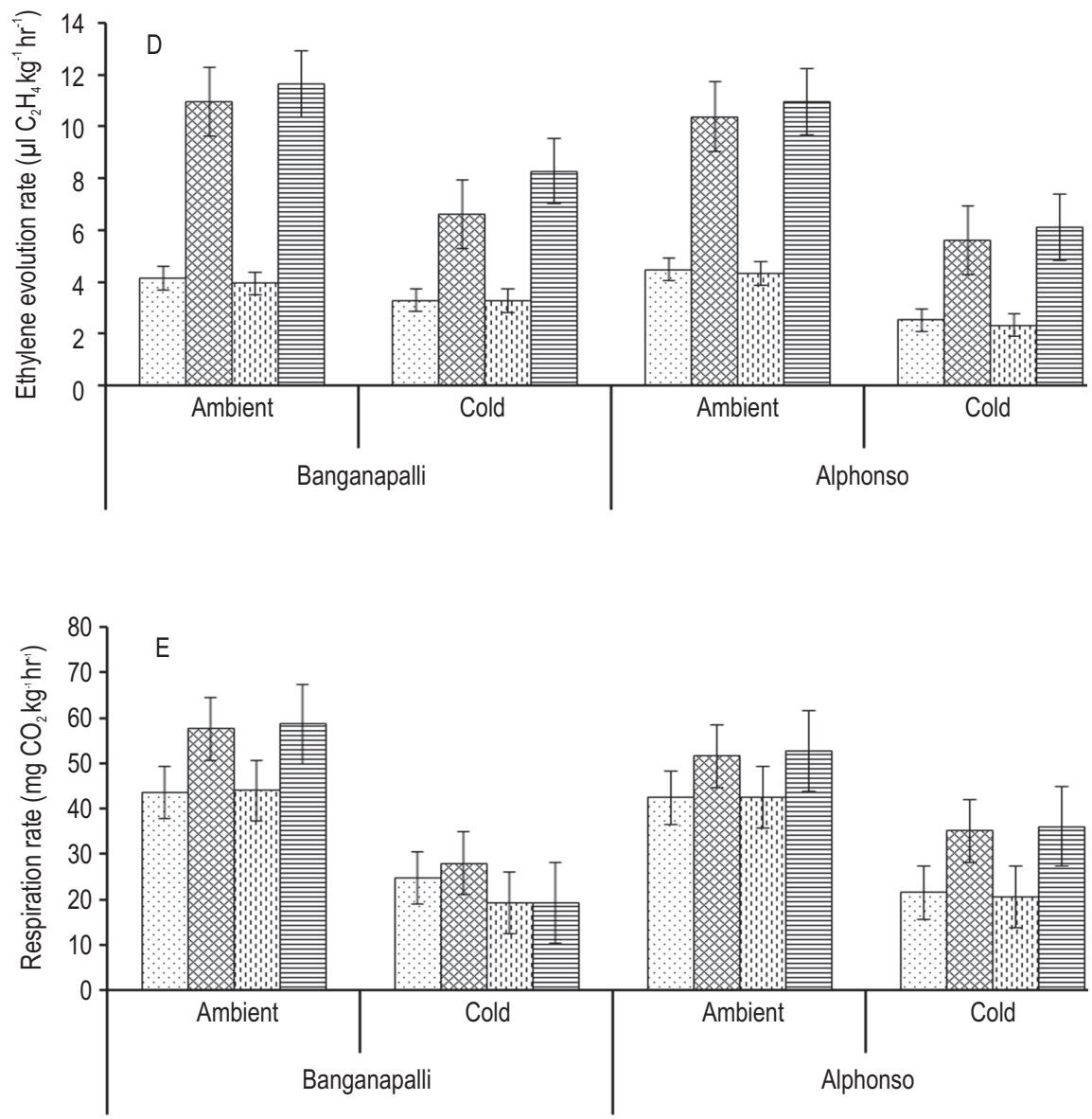

$\square S-2 \%$ hexanal formulation as pre-harvest spray; $\quad \square$ SD $-2 \%$ hexanal formulation as pre-harvest spray and post-harvest dip $\square D-2 \%$ hexanal formulation as post-harvest spray and $\square \mathrm{C}$ - Untreated fruits

Fig. 1(b): Influence of hexanal formulation on shelf life ethylene evolution rate (D) and respiration rate (E) of mango cultivars under ambient and cold storage condition.

secondary metabolites and provides protection against disease or pest attack (Scalbert et al., 2005). Increase in sugars, carotenoids and flavonoids due to pre- and post-harvest hexanal application on tomato (Cheema et al., 2014), guava (Gill et al., 2016) and mango (Anusuya etal., 2016) has been reported previously.

Fruit ripening is a sequential oxidative phenomenon that needs a turnover of active oxygen species like hydrogen peroxide and superoxide anion to protect the lipid membrane, nucleic acids and proteins against oxidative injury caused by reactive oxygen species (ROS) (Jimenez et al., 2001). Free radicals and ROS are generated at the end of electron transporting chain during respiration in fruits (Masibo and He, 2008). Ascorbic acid is an important substrate for respiration, bioactive metabolite and a dietary antioxidant for human. In order to scavenge the generated
ROS like superoxide anion radical, hydroxyl radical and hydrogen peroxide, upholding the enzymatic system through oxygen consumption or exogenous supply of antioxidant is essential (Ma et al., 2011). Hexanal formulation, slow down the depletion of ascorbic acid significantly by reducing the respiration rate (Table 1). Increasing concentration of hexanal formulation positively reduced the depletion rate of ascorbic acid. Higher dose of hexanal formulation significantly altered the ascorbic acid under ambient and cold storage condition. Spray and spray combined with dip treatment of hexanal increased the ascorbic acid content upto 0.44 to $0.77 \mathrm{mg} 100 \mathrm{~g}^{-1}$ of pulp in $\mathrm{cv}$.

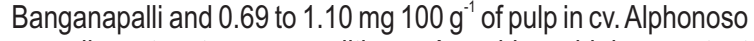
regardless to storage conditions. Ascorbic acid is a potent antioxidant against oxidation-reduction and increases the total antioxidant activity (Periago et al., 2009). However, hexanal 

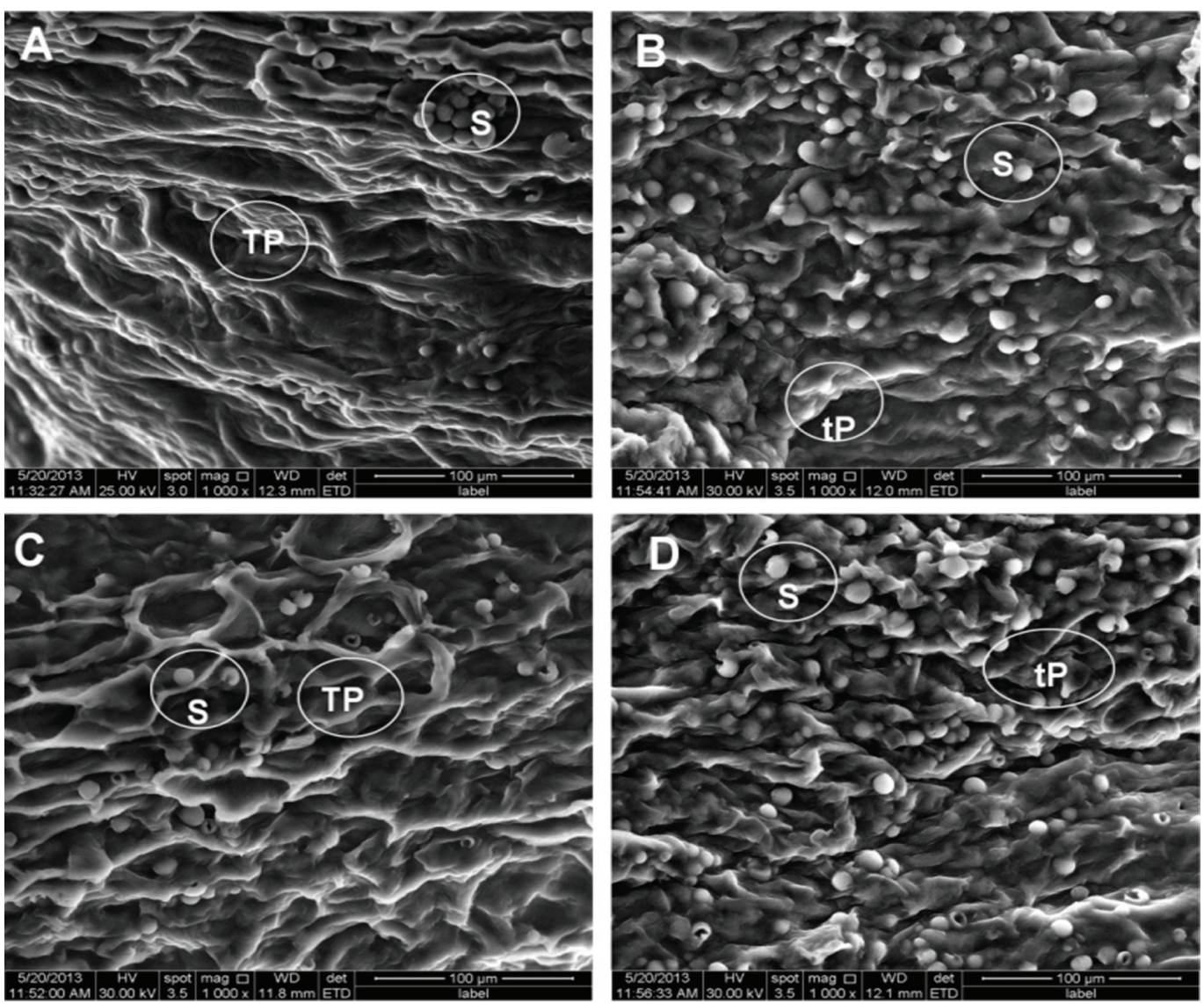

Fig. 2 : Scanning electron micrographs depicting starch hydrolysis in the control $(A, C)$ and hexanal treated $(B, D)$ mango fruits of cv. Banganapalli and Alphonso, after a week storage. S - Starch granules; TP - Thick parenchyma; tP - Thin parenchyma
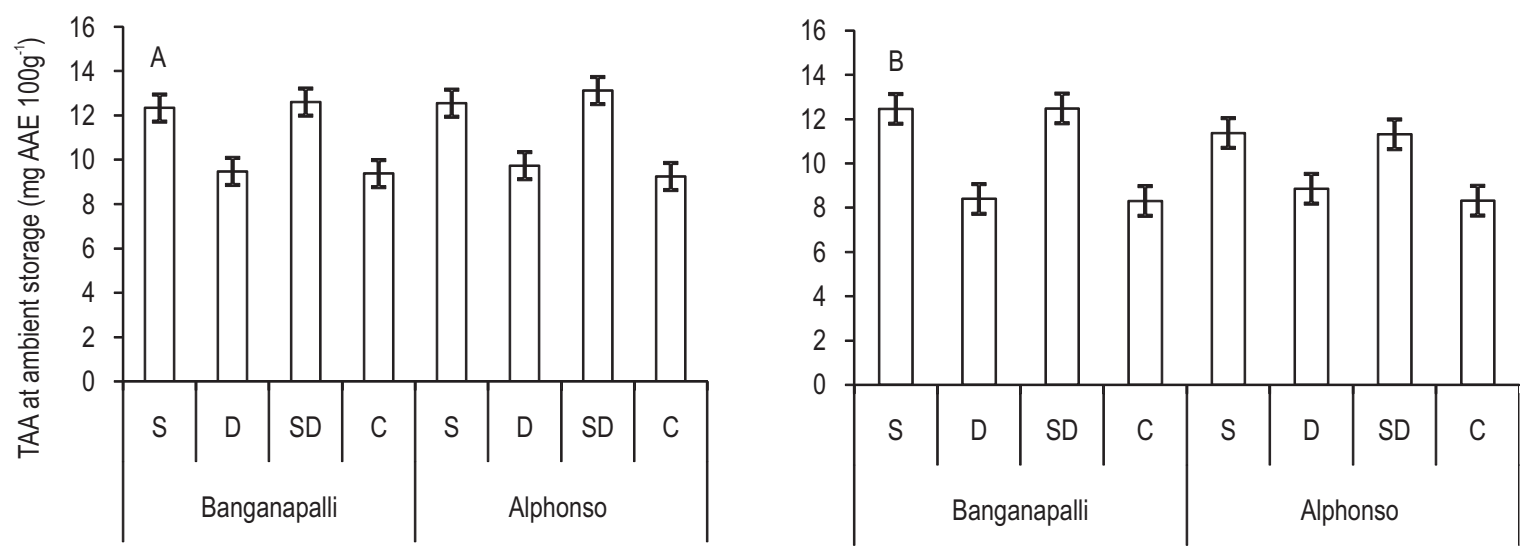

S $-2 \%$ hexanal formulation as pre-harvest spray $\quad S D-2 \%$ hexanal formulation as pre-harvest spray and post-harvest dip

D - $2 \%$ hexanal formulation as post-harvest spray C - Untreated fruits

Fig. 3 : Influence of hexanal formulation on total antioxidant activity of mango cultivars under ambient (A) and cold storage condition (B). 


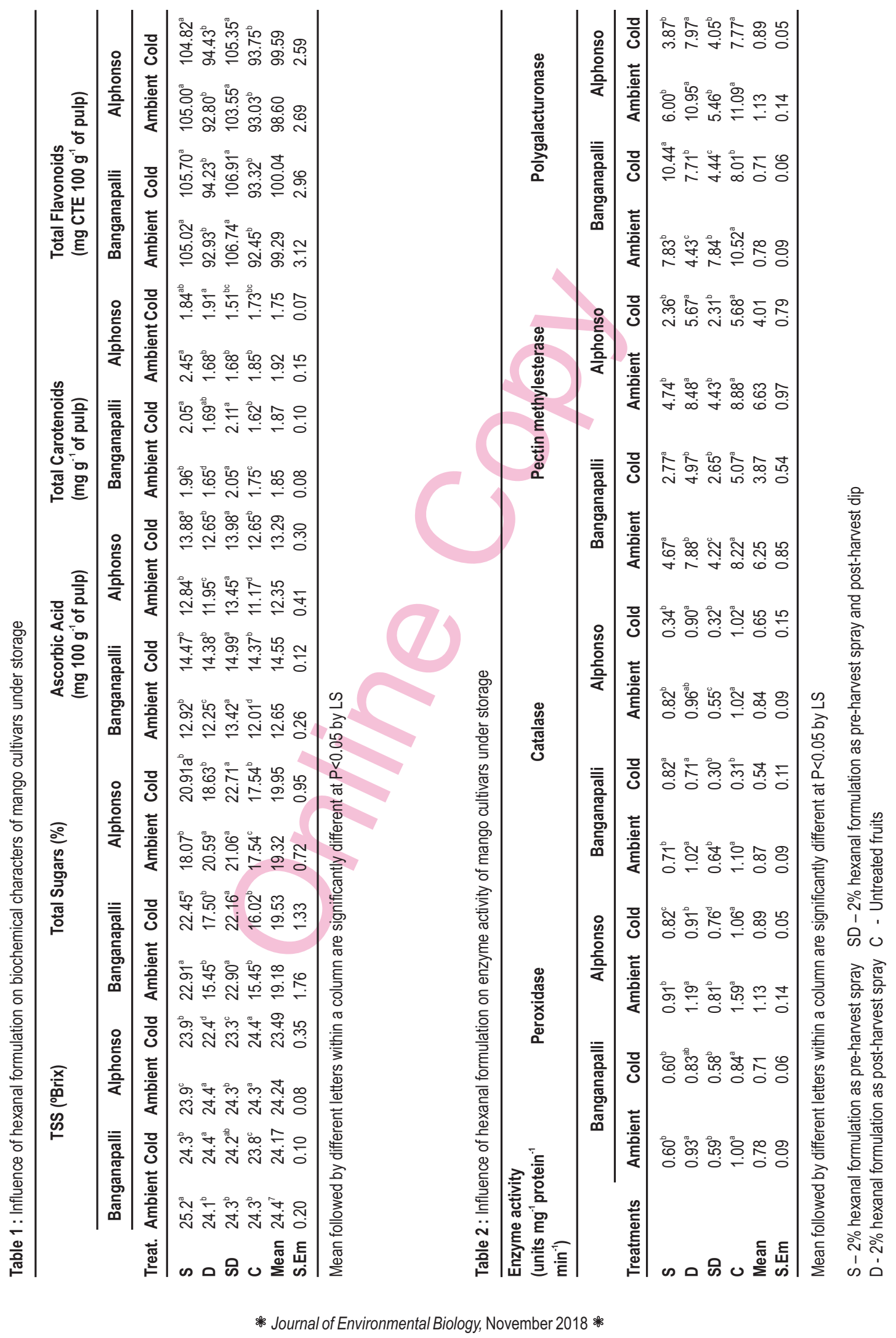


formulation showed effect on total antioxidant activity regardless to storage conditions and cultivars (Fig. 3A,B). It acts on phenolic compounds and temporarily ceases the substrate supply for polyphenoloxidase activity (Lanciotti et al., 2004). Higher respiration rate reduces the ascorbic acid and total antioxidant activity in fruits and vegetables. Hexanal showed promising results in reducing the respiration rate and there by less depletion of ascorbic acid and higher activity of antioxidant. The results on ascorbic acid and antioxidant properties obtained by researchers on various crops are similar to the results stated that ethylene inhibitors and Phospholipase-D inhibitor might cease the synthesis of Vit.-C precursor and promote the accumulation of active oxygen species during the initial days of storage (Anusuya et al., 2016; Reddy et al., 2016).

Right from detachment from mother tree, harvested fruits undergo several stress conditions i.e., heat and cold injury due to eratic temperature, tissue damage and infection by pathogens. Catalase (CAT) and Peroxidase (POX) are enzymatic antioxidants provides protection against various stress conditions and thereby extend the shelf life (Cano et al., 1995; Martınez-Tellez and Lafuente, 1997). Hexanal formulation appropriately reduced the action of CAT and POX (Table 2), because it slowdown the progress of senescence by maintaining cell membrane integrity. Application of hexanal formulation twice or thrice significantly reduces the mean POX activity from 1.12 to 0.69 units $\mathrm{mg}^{-1}$ protein $\mathrm{min}^{-1}$ across cultivars and storage conditions. Similarly, the mean CAT activity was reduced from

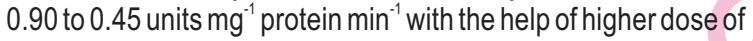
hexanal application invariable to storage conditions. Hence, hexanal formulation influenced the role of non-enzymatic antioxidants i.e., ascorbic acid, total carotenoids, total flavonoids and antioxidant enzymes i.e., CAT and POX on scavenging the free radicals. The detailed study on antioxidant enzyme activity of mango fruits due to hexanal application were similar with the result obtained in this experiment (Saxena et al., 2014; Jincy et al., 2017).

The major textural changes resulting in softening of the fruits are due to enzyme mediated alteration in the structure and composition of cell wall, partial or complete solubilization of cell wall polysaccharides i.e., pectins and celluloses (Tucker and Grierson, 1987). Polygalacturanase along with pectin methylesterase promotes cell wall disintegration which could lead to higher moisture and physiological weight loss. Hexanal formulation applied as spray, spray and dip had a greater influence in reducing the action of PME and PG (Table 2). Nearly, two fold decrease in mean PME activity (reduced from 7.00 to 3.50 units $\mathrm{mg}^{-1}$ protein min $^{-1}$ ) and mean PG activity (units $\mathrm{mg}^{-1}$ protein $\mathrm{min}^{-1}$ ) was noticed in hexanal formulation treated fruits. When hexanal treated mango fruits stored under cold and ambient condition, the reduced activity was recorded by Anusuya et al. (2016) with respect to fruit softening enzyme. The results of the study conclude that pre and post-harvest application of hexanal treatments coupled with cold storage offers a significant potential in reducing the post-harvest losses and increase the shelf life.

\section{Acknowledgments}

The authors acknowledge the International Development Research Centre (IDRC), Ottawa, The Government of Canada and Foreign Affairs, Trade and Development Canada (DFATD) for financial support throughout the research period. The authors also thank Department of Nano Science and Technology, Tamil Nadu Agricultural University for providing scanning electron microscope for histological study.

\section{References}

Akamine, E.K. and T. Goo: Respiration and ethylene production during ontogeny of fruit. J. Am. Soc. Hort. Sci., 98, 286-291 (1973).

Anusuya, P., R. Nagaraj, G.J. Janavi, K.S. Subramanian, G. Paliyath and J. Subramanian : Pre-harvest spray of hexanal formulation for extending retention and shelf life of mango (Mangifera indica L.). Sci. Hort., 211, 231-240 (2016).

AOAC: Official methods of analysis of the Association of Official Analytical Chemists. $15^{\text {th }}$ Edn., Association of Official Analytical Chemists, Arlington VA., pp.1058-1059 (1990).

Babalar, M., M. Asghari, A. Talaei and A. Khosroshahi: Effect of pre and post harvest salicylic acid treatment on ethylene production, fungal decay and overall quality of Selva strawberry fruit. Food Chem., 105, 449-53 (2007).

Brecht, J. K. and E.M. Yahia : The mango: Botany, production and uses. $2^{\text {nd }}$ Edn., CAB International, Florida, p. 491 (2009).

Bretch, J. K. and E. M. Yahia : Postharvest Physiology : Compositional Changes during fruit Maturation and Ripening. In : The Mango: Botany, Production and Uses (Ed.: R.E. Litz). $2^{\text {nd }} E d n$., CAB International, pp. 484-528 (2009).

Brown, J.H., G. Paliyath and J.E. Thompson : Influence of acyl chain composition on the degradation of phosphatidylcholine by phospholipase $D$ in carnation microsomal membranes. J. Exp. Bot., 229, 979-986 (1990).

Burg, S.P. and E.A. Burg : Ethylene action and the ripening of fruits. Science, 148, 1190-1196 (1965).

Cano, M.P., B.D. Ancos and G. Lobo: Peroxidase and polyphenoloxidase activities in papaya during postharvest ripening and after freezing/thawing. J. Food Sci., 60, 815-818(1995).

Cheema, A., P. Padmanabhan, J. Subramanian, T. Blom and G. Paliyath: Improving quality of greenhouse tomato (Solanum lycopersicum L.) by pre and post harvest applications of hexanal-containing formulations. Posthar. Biol. Technol, 95, 13-19 (2014).

Corbo, M.B., R. Lanciotti, F. Gardini, M. Sinigaglia and M.E. Guerzoni: Effects of hexanal, trans-2-hexenal, and storage temperature on shelf life of fresh sliced apples. J. Agric. Food Chem., 48, 2401-2408 (2000).

Gigot, C., M. Ongena, F. Marie-Laure, W. Jean-Paul, P.D. Jardin and P. Thonart: The lipoxygenase metabolic pathway in plants : Potential for industrial production of natural green leaf volatiles. Biotechnol. Agron. Soc. Environ., 14, 451-460 (2010).

Gill, K. S., H. S. Dhaliwal, B. V. C. Mahajan, G. Paliyath and R. S. Boora: Enhancing postharvest shelf life and quality of guava (Psidium guajava L.) Cv. Allahabad Safeda by pre-harvest application of hexanal containing aqueous formulation. Posthar. Biol. Technol., 112, 224-232 (2016).

Graf, B.A., P.E. Milbury and J.B. Blumberg: Flavonol, flavones, flavanones and human health : Epidemiological evidence. J. Med. Food, 8, 281-290 (2005). 
Gunjate, R.T., D.P. Walimbe, B.L. Lad and V.P. Limaye: Development of internal breakdown in "Alphonso" mango by postharvest exposure of fruits to sunlight. Sci. Cult., 48, 188-190 (1982).

Hagerman, A. E. and P. J. Austin: Continuous spectrophotometric assay for plant pectin methyl esterase. J. Agric. Food Chem., 34, 440-444 (1986).

Hedge, J. E. and B. T. Hofreiter : Methods in Carbohydrate Chemistry. $17^{\text {th }}$ Edn., New YorkAcademic Press, New York, p. 420 (1962).

Hossain, F., A. K. Parvez, M. K. Munshi, I. Khalil and R. Huque: Postharvest treatments of radiation and chemical on organoleptic and biochemical properties of mango (Mangifera indica L.) in relation to delay ripening. American-Eurasian J. Agric. Environ. Sci., 14, 555-564 (2014)

Huang, D., B. Ou and R. L. Prior: The chemistry behind antioxidant capacity assays. J. Agric. Food Chem., 53, 1841-1856 (2005).

Jandus, J., O. Valentova and J. Kas : Phospholipase D during tomato fruit ripening. Plant Physiol. Biochem., 35, 123-128 (1997).

Jensen, A.: Chlorophylls and Carotenoids. In: Handbook of Phytological Methods (Eds.: A. Hellebust and J. S. Crargie). Cambridge Univ. Press, London, pp. 59-72 (1978)

Jha, S. N., P. Jaiswal, K. Narsaiah, P.P. Kaur, A. K Singh and R. Kumar: Textural properties of mango cultivars during ripening. J. Food Sci. Tech., 50, 1047-1057 (2013).

Jimenez, A., R. Rodriguez, I. Fernandez-Caro, R. Guillen, J. FernandezBolanos and A. Heredia: Olive fruit cell wall: degradation of pectic oligosaccharides during ripening. J. Agric. Food Chem., 49, 409415(2001).

Jincy, M., M. Djanaguiraman, P. Jeyakumar, K.S. Subramanian, J. Subramanian and G. Paliyath : Inhibition of phospholipase D enzyme activity through hexanal leads to delayed mango (Mangifera indica L.) fruit ripening through changes in oxidants and antioxidant enzymes activity. Sci. Hort., 218, 316-325 (2017).

Lanciotti, R., A. Gianotti, F. Patrignani, N. Belletti, M.E. Guerzoni and F. Gardini: Use of natural aroma compounds to improve shelf-life and safety of minimally processed fruits. Trends Food Sci. Technol.,15, 201-208 (2004)

Lima, L. C. D. O., A.B. Chitarra and M. I. F. Chitarra: Changes in amylase activity starch and sugars contents in mango fruits pulp cv. Tommy Atkins with spongy tissue. Brazilian Arch. Biol. Technol., 44, 59-62 (2001).

Lownds, N.K., M. Banaras and P.W. Bosland : Relationships between postharvest water loss and physical properties of pepper fruit (Capsicum annuumL.). HortScience, 28, 1182 -1184 (1993).

Luck, $H .:$ Methods in Enzymatic Analysis. $2^{\text {nd }}$ Edn., Bergmeyer Academic Press, New York, p. 885 (1974).

Ma, X., H. Wu, L. Liu, Q. Yao, S. Wang, R. Zhan, S. Xing and Y. Zhou: Polyphenolic compounds and antioxidant properties in mango fruits. Sci. Horti., 129, 102-107 (2011).

Mallik, C. P. and M. P. Singh: Plant Enzymology and Histoenzymology. Kalyani Publishers, New Delhi (1980)

Martınez-Tellez, M.A. and M.T. Lafuente : Effect of high temperature conditioning on ethylene, phenylalanine ammonia-lyase, peroxidase and polyphenol oxidase activities in flavedo of chilled "Fortune" mandarin fruit. J. Plant Physiol.,150, 674-678 (1997).

Masibo, M. and Q. He : Major mango polyphenols and their potential significance to human health. Comp. Rev. Food Sci. Food Saf., 7, 309-319 (2008).

Nunes, M. C. N., J. P. Emond, J. K. Brecht, S. Dea and E. Proulx: Quality curves for mango fruit (cv. Tommy Atkins and Palmer) stored at chilling and nonchilling temperatures. J. Food Quality, 30, 104-120 (2007).

Oke, M., R.G. Pinhero and G. Paliyath : The effects of genetic transformation of tomato with antisense phospholipase D cDNAon the quality characteristics of fruits and their processed products. Food Biotechnol., 17, 163-182(2003).

Paliyath, G. and D.P. Murr: Biochemistry of Fruits. In: Postharvest Technology and Biology of Fruits, Vegetables and Flowers (Eds.: G. Paliyath, D.P. Murr, A.K. Handa and S. Lurie). Wiley-Blackwell, A John Wiley \& Sons Ltd., Publication, pp.40-48 (2008).

Paliyath, G. and J. Subramanian: Phospholipase D Inhibition Technology for Enhancing Shelf Life and Quality. In: Postharvest Technology and biology of Fruits, Vegetables and Flowers (Eds.: G. Paliyath, D.P. Murr, A.K. Handa and S. Lurie). Wiley - Blackwell, A John Wiley \& Sons Ltd. Publication, pp. 244-245 (2008).

Periago, M.J., J. García-Alonso, K.Jacob, A.B. Olivares, M.J. Bernal, M.D. Iniesta, C. Martínez and G. Ros: Bioactive compounds, folates and antioxidant properties of tomatoes (Lycopersicum esculentum) during vine ripening. Int. J. Food Sci. Nutr., 60, 694-708 (2009)

Pinhero, R.G., K.C. Almquist, Z. Novotna and G. Paliyath: Developmental regulation of phospholipase $D$ in tomato fruits. Plant Physiol. Biochem., 41, 223-240 (2003).

Prieto, P., M. Pineda and M. Aguilar: Spectrophotometric quantitation of antioxidant capacity through the formation of a phosphomolybdenum complex : Specific application to the determination of vitamin E. Anal. Biochem., 269, 337-41 (1999).

Reddy, S.V.R., R.R. Sharma, M, Srivastava and C. Kaur. Effect of preharvest application of salicylic acid on postharvest behaviour of 'Amrapali' mango fruits during storage. Indian J. Hort., 73, 405-409 (2016).

Saxena, P., V.K. Singh and N. Pathak: Antioxidative enzymes and biochemical changes in paclobutrazol induced flowering in mango cultivars. J. Environ. Biol., 35, 1061-1066 (2014).

Scalbert, A., C. Manach, C. Morand and C. Remesy: Dietary polyphenols and the prevention of diseases. Crit. Rev. Food Sci. Nutr., 45, 287-306 (2005).

Schade, F., J.E. Thompson and R. Legge: Use of plant-derived enzyme template for the production of the green-note volatile hexanal. Biotech. Bioengg., 84, 265-272 (2003).

Sharma, R. R. and R. Singh : The fruit pitting disorder-A physiological anomaly in mango (Mangifera indica L.) due to deficiency of calcium and boron. Sci. Hort., 119, 388-391 (2009)

Sharma, M., J.K. Jacob, J. Subramanian and G. Paliyath: Hexanal and 1MCP treatments for enhancing the shelf life and quality of sweet cherry (Prunus avium L.). Sci. Hort., 125, 239-247 (2010).

Singh, P., M.K. Singh, V. Kumar, M. Kumar and S. Malik: Effect of physiochemical treatments on ripening behavior and post-harvest quality of Amrapali mango (Mangifera indica L.) during storage. J. Environ. Biol., 33, 227-232 (2012).

Singh, S.P. and D.V.S. Rao: Effect of modified atmosphere packaging on the alleviation of chilling injury and dietary antioxidants levels in 'Solo' papaya during low temperature storage. European J. Hortic. Sci., 70, 246-252 (2005).

Spotts, R.A., P.L. Sholberg, P. Randall, M. Serdani and P.M Chen: Effects of 1-MCP and hexanal on decay of d'Anjou pear fruit in long term storage. Posthar. Biol. Technol., 44, 101-106 (2007).

Tucker, G.A. and D. Grierson : Fruit Ripening. In: The Biochemistry of Plants- A comprehensive treatise (Ed.: D.D. Davies). Academic Press, Vol. 12, pp. 256-318 (1987).

Zainon, M. L. and C. J. Brady : Purification and characterization of the polygalacturonase of tomato fruits. Aust. J. Plant Physiol., 9, 155169 (1982).

Zhishen. J., T. Mengcheng and W. Jiaming : The determination of flavonoid contents in mulberry and their scavenging effects on superoxide radicals. Food Chem., 64, 555-559 (1999). 